\title{
Isolation, structure determination and structure-activity relationship of anti-toxoplasma triterpenoids from Quercus crispula Blume outer bark
}

\author{
Marina Endo ${ }^{1}$, Kengo Shigetomi ${ }^{1 *}\left(\mathbb{D}\right.$, Shinya Mitsuhashi ${ }^{2}$, Makoto Igarashi ${ }^{3}$ and Makoto Ubukata ${ }^{1}$
}

\begin{abstract}
Toxoplasma gondii is an intracellular protozoan parasite of which infection can result in serious symptoms for fetuses or people who have weakened immune system. In our effort to discover novel anti-toxoplasma substances from tree barks, only outer bark extract from Quercus crispula Blume (mizunara) was revealed to show potent anti-toxoplasma activity. Isolation of the active principles was performed to identify three pentacyclic triterpenoids, namely 29-norlupane-3,20-dione, oleanolic acid acetate and ursolic acid acetate. These structures were determined by combining a series of spectral data, computational simulation and synthetic approach. All isolated compounds exhibited notable activities at $I C_{50}$ of 6.8-24.4 $\mu \mathrm{M}$ and high selectivities against the parasite. The structure-activity relationship study conducted to probe key structure(s) indicated that the lack of free hydroxyl group at 3-position highly contributes to both the titer of activity and the selectivity. Moreover, skeleton and functionalities of E-rings were also suggested to affect to the activity. The present study demonstrated not only that the extract from Q. crispula Blume could be a promising source of toxoplasmacidal agent, but also that related extractive triterpenoids can be modified to furnish anti-toxoplasma activity.
\end{abstract}

Keywords: Toxoplasma gondii, Triterpenoids, Quercus crispula, Mizunara, Paraciticide

\section{Introduction}

Toxoplasma gondii is an intracellular protozoan parasite that can infect all warm-blood animals including humans. The infection to humans occurs transplacentally, or orally thorough infectious cat, contaminated soil, water or raw/undercooked meat. Although most people infected with Toxoplasma do not show symptoms, the parasite can cause hydrocephalus or stillbirth in the fetus and cause toxoplasmic encephalitis in people with weakened immune system [1, 2]. Regardless of its severity and worldwide distribution, toxoplasmosis has gained relatively little attention for its prevention or treatment mainly due to economic reasons. Therefore, this disease

\footnotetext{
*Correspondence: sgtm@for.agr.hokudai.ac.jp

${ }^{1}$ Division of Applied Bioscience, Graduate School of Agriculture,

Hokkaido University, N9 W9, Sapporo 060-8589, Japan

Full list of author information is available at the end of the article
}

is designated as the neglected parasitic infections (NPIs) by Centers for Disease Control and Prevention in United States [3]. Currently, pyrimethamine and sulfadiazine are used as first-line medicines for treatment of toxoplasmosis, but their high rates of toxic side effects often prevent continuous administration [4].

The bark is one of the most abundant biomass and is currently used as heat sources, livestock bedding or feedstuffs after wood bark peeling. However, their sophisticated applications utilizing bark-specific characteristics have not yet been established. Focusing on the richness and the diversity of secondary metabolites in tree barks, we demonstrated the inhibitory activity of extracts from 8 species of northern tree barks on advanced glycation end-products (AGEs) formation and identified the active ingredients in previous work [5]. In this study, the search for toxoplasmacidal activity from bark extracts was conducted and the identification of active principles from 
Quercus crispula Blume outer bark was investigated by bioassay-guided isolation followed by extensive structure elucidation. Moreover, we report a structure-activity relationship study of isolated pentacyclic triterpenoids to gain a new insight into the development of toxoplasmacidal drugs.

\section{Materials and methods}

Measurement of anti-toxoplasma activity

In vitro growth assay of $T$. gondii was conducted according to the previously reported method [6]. Briefly, one thousand $T$. gondii RH strain parasites were inoculated into each well of a confluent human fibroblast culture in a 96-well plate. One day after infection, samples were applied with various concentrations. Three days after sample apply, culture supernatants were collected and the amount of MIC10 antigen was determined by the sandwich ELISA. The amount of MIC10 antigen was expressed as optical density $\left(\mathrm{OD}_{415}\right)$ value determined by a microplate reader (MTP-500, Corona Electric, Japan).

Cytotoxicity of each sample on human foreskin fibroblast was determined as follows. Human fibroblast was cultured in a 96 -well plate as $50 \%$ confluent. Next day, samples were applied with various concentrations. After 2 days culture, cell viabilities were determined by formazan dye (Cell Counting Kit-8, Dojindo Molecular Technologies, Inc., Kumamoto, Japan).

\section{Screening of anti-toxoplasma extract from tree barks}

Barks of eight species, namely Abies sachalinensis, Larix kaempferi, Betula platyphylla, Phellodendron amurense, Ulmus davidiana var. japonica, Aria alnifolia, Quercus crispula Blume, and Acer mono Maxim., were collected at Tomakomai Research Forest, Field Science Center for Northern Biosphere, Hokkaido University $\left(42^{\circ} 40^{\prime} \mathrm{N}, 141^{\circ} 35^{\prime} \mathrm{E}\right)$ in May 2011 . After harvest, outer and inner barks were separated manually and the methanolic extracts were prepared following the procedure described in reference 5. A total of 14 methanolic extracts (outer barks from A. sachalinensis and B. platyphylla and outer and inner barks of the remaining species) were dissolved in dimethyl sulfoxide (DMSO) at $10 \mu \mathrm{g} / \mathrm{mL}$, and each sample was subjected to the assay. DMSO and nitazoxanide ( 1 and $2 \mu \mathrm{M})$ were used as negative and positive controls, respectively.

\section{Isolation of anti-toxoplasma compounds from Quercus crispula Blume outer bark}

Seven-hundred and seventy-seven grams of pulverized Quercus crispula Blume outer bark was treated with 60 -fold amount of $\mathrm{CHCl}_{3}(\mathrm{w} / \mathrm{w})$ under mechanical stirring for $2.5 \mathrm{~h}$. Filtration and extraction were repeated three times and combined filtrate was evaporated in vacuo, resulting in brown residue of $31.4 \mathrm{~g}$. The half was subjected to flash silica gel column chromatography (Kanto Chemical, Silica Gel N60 spherical neutral) eluting with EtOAc:hexane $=1: 9$ to 1:7. Fractions were collected every $15 \mathrm{~mL}$ and were combined based on thinlayer chromatography (TLC) pattern. The fraction with an $R_{\mathrm{f}}$ value of $\approx 0.4$ on TLC (EtOAc:hexane $=1: 4$ ) was evaporated and rechromatographed on silica gel column eluting with EtOAc:hexane =1:10 to 1:7 to give $273.5 \mathrm{mg}$ of crude fraction. In each step, active fractions were identified by the bioassay described above. One-hundred and forty-eight milligrams of crude fraction was then purified with reverse phase high-performance liquid chromatography (HPLC). Preparative HPLC was first performed with Mightysil RP-18 GP II $\phi 20 \times 250 \mathrm{~mm}$ (Kanto Chemical, Tokyo, Japan) with eluting $\mathrm{H}_{2} \mathrm{O}: \mathrm{MeOH}=7: 93$ $(+0.1 \% \mathrm{AcOH})$ at $15.0 \mathrm{~mL} / \mathrm{min}$ flow rate. UV detection was carried out at $210 \mathrm{~nm}$. Among three major peaks detected, the peak with retention time (RT) of $12.15 \mathrm{~min}$ was recovered and evaporated to give $28.0 \mathrm{mg}$ of pure compound (compound 1). The peak at RT $13.25 \mathrm{~min}$ was likewise recovered as a two-component mixture (40.5 mg). The mixture was next separated into two fractions with the HPLC system equipped with PLC-6RcA recycle-valve system (GL Science, Tokyo, Japan). All conditions were same as 1st preparative HPLC, except the elution with $\mathrm{H}_{2} \mathrm{O}: \mathrm{MeOH}=8: 92(+0.1 \% \mathrm{AcOH})$. After injection, the valve was switched to recycle position in $10 \mathrm{~min}$ and the recycle was repeated eight times. From resulting bimodal peak, only pure parts of two compounds were recovered as compound $2(\mathrm{RT}=82.11 \mathrm{~min})$ and compound $3(\mathrm{RT}=83.59 \mathrm{~min})$, respectively.

\section{Computational prediction of ${ }^{13} \mathrm{C}$ chemical shift}

All calculations were performed using the Spartan'16 (Wavefunction Inc., Irvine, CA, USA) [7]. The structures of 29-norlupan-3,20-dione and 29-nor-21 $\alpha H$-hopane3,22-dione were built and the conformer distribution was first analyzed by MMFF in gas. After geometry optimization of all conformers by Hartree-Fock/3-21G, energies were evaluated using density functional (DF)/ $\omega \mathrm{B} 97$ $\mathrm{X}-\mathrm{D} / 6-31 \mathrm{G}^{*}$ calculation. Geometry optimization and energy calculation were repeated using $\mathrm{DF} / \omega \mathrm{B} 97 \mathrm{X}-\mathrm{D} / 6$ $31 \mathrm{G}^{*}$ and $\mathrm{DF} / \omega \mathrm{B} 97 \mathrm{X}-\mathrm{V} / 6-311+\mathrm{G}(2 \mathrm{df}, 2 \mathrm{p})$, respectively. Finally, six conformers of 29-norlupan-3,20-dione and eight conformers of 29-nor-21 $\alpha H$-hopane-3,22-dione were obtained without discarding high-relative energy conformers $(>10 \mathrm{~kJ} / \mathrm{mol})$ through the process. NMR shift prediction was carried out using DF/ $\omega B 97$ X-D/6$31 \mathrm{G}^{*}$ calculation and the resulting shifts were calibrated based on Boltzman distribution in DF/ $\omega \mathrm{B} 97 \mathrm{X}-\mathrm{V} / 6$ $311+\mathrm{G}(2 \mathrm{df}, 2 \mathrm{p})$ energy simulation. 


\section{Instrumental analyses of isolated and synthetic compounds}

All ${ }^{1} \mathrm{H},{ }^{13} \mathrm{C},{ }^{1} \mathrm{H}-{ }^{1} \mathrm{H}$ COSY, HMBC, HSQC and NOESY NMR spectra of isolated compounds were measured with an AMX-500 (Bruker, Billeria, MA, USA) (500 MHz and $125 \mathrm{MHz}) .{ }^{1} \mathrm{H}$ and ${ }^{13} \mathrm{C}$ NMR spectra of synthetic compounds were measured with a JNM-EX270 (JEOL, Tokyo, Japan) (270 MHz and 67.5 MHz). Chemical shifts are defined using tetramethylsilane as the internal standard and expressed in $\delta \mathrm{ppm}$. Mass spectra were acquired with FD techniques using a JMS-T100GCV (JEOL) or EI techniques by a JMS-SX102A (JEOL). All NMR spectra on AMX-500 were measured at the GC-MS and NMR Laboratory, Faculty of Agriculture, Hokkaido University. Optical rotations were determined on a P-2200 polarimeter (JASCO, Tokyo, Japan) in a $\phi 3.4 \times 50 \mathrm{~mm}$ cell at $25{ }^{\circ} \mathrm{C}$. A part of physicochemical data of isolated compounds is as follows: Compound 1: $[\alpha]_{\mathrm{D}}^{25}+13.9(c$ 1.00, $\mathrm{CHCl}_{3}$ ); HR-FI-MS $m / z[\mathrm{M}]^{+}$: calcd. for $\mathrm{C}_{29} \mathrm{H}_{46} \mathrm{O}_{2}$, 426.3498; found, 426.3510; Compound 2: $[\alpha]_{\mathrm{D}}^{25}+48.1(c$ $0.49, \mathrm{CHCl}_{3}$ ); HR-FD-MS $m / z[\mathrm{M}]^{+}$: calcd. for $\mathrm{C}_{32} \mathrm{H}_{50} \mathrm{O}_{4}$, 498.3709; found, 498.3729; Compound 3: $[\alpha]_{\mathrm{D}}^{25}+46.6(c$ 0.99, $\mathrm{CHCl}_{3}$ ); HR-FD-MS $m / z[\mathrm{M}]^{+}$: calcd. for $\mathrm{C}_{32} \mathrm{H}_{50} \mathrm{O}_{4}$, 498.3709; found, 498.3710. NMR peak lists are presented in Tables 1 and 2.

\section{Gas chromatography/Mass spectrometry (GC-MS) analysis} $1.0 \mathrm{mg}$ of methanolic bark extract, $0.1 \mathrm{mg}$ of isolated compounds 1-3, commercial ursolic acid (SigmaAldrich, St. Louis, MO, USA) and oleanolic acid (TCI, Tokyo, Japan) were derivatized with $200 \mu \mathrm{L}$ of $N, O-$ bis(trimethylsilyl)trifluoroacetamide and diluted with $800 \mu \mathrm{L}$ of $\mathrm{CHCl}_{3}$. One microliter of each solution was analyzed by GC-2010/QP-2010 system (Shimadzu, Kyoto, Japan) under following conditions: column: BPX5 $30 \mathrm{~m}$, $\phi 0.25 \mathrm{~mm}, d f 1.0 \mu \mathrm{m}$ (SGE analytical science, Melbourne, Australia); injection unit: $300{ }^{\circ} \mathrm{C}$; column oven: $340{ }^{\circ} \mathrm{C}$; carrier gas control: constant linear velocity $(44.5 \mathrm{~cm} / \mathrm{sec})$; carrier gas: helium; interface: $250{ }^{\circ} \mathrm{C}$; ion source: $250{ }^{\circ} \mathrm{C}$. Chromatograms were obtained by monitoring $m / z 426$, the parent ion of 29-norlupan-3,20-dione, and $m / z 320$, the $\mathrm{C}-\mathrm{D}-\mathrm{E}$ ring fragment $\left(\mathrm{C}_{19} \mathrm{H}_{32} \mathrm{O}_{2} \mathrm{Si}\right)$ of other triterpenoids. Retention times of authentic compounds were as follows: BisTMS-ursolic acid: $10.41 \mathrm{~min}$; BisTMSoleanolic acid: $11.30 \mathrm{~min}$; 29-norlupan-3,20-dione: $12.28 \mathrm{~min}$; TMS-oleanolic acid acetate: $12.53 \mathrm{~min}$; TMSursolic acid acetate: $13.69 \mathrm{~min}$.

\section{Synthesis of 28-O-p-toluenesulfonyl betulin (5)}

To the solution of betulin $(1.92 \mathrm{~g}, 4.34 \mathrm{mmol})$ in $18 \mathrm{~mL}$ of pyridine, $p$-toluenesulfonyl chloride $(860 \mathrm{mg}, 4.51 \mathrm{mmol})$ solution in $2.0 \mathrm{~mL}$ of pyridine was added dropwise at
$0{ }^{\circ} \mathrm{C}$. After 2 days stirring, $400 \mathrm{mg}$ of $p$-toluenesulfonyl chloride was added portionwise. The reaction was allowed to stir for another day. Pyridine was azeotropically removed with toluene and the resulting mixture was subjected to flash silica gel column chromatography with EtOAc:toluene $=1: 4$ as an eluent. UV-absorbing fractions were collected and evaporated. The crude product was recrystallized with EtOAc- $\mathrm{CH}_{2} \mathrm{Cl}_{2}$ system to give $593.1 \mathrm{mg}(23 \%)$ of betulin 28-tosylate as white solid. ${ }^{1} \mathrm{H} \mathrm{NMR}\left(\mathrm{CDCl}_{3}, 270 \mathrm{MHz}\right): \delta 0.76,0.77,0.79,0.90$ and $0.96(15 \mathrm{H}, \mathrm{s}, \mathrm{H}-23,24,25,26$ and 27$), 1.63(3 \mathrm{H}, \mathrm{s}$, $\mathrm{H}-30), 2.27$ (1H, m, H-19), $2.46\left(3 \mathrm{H}, \mathrm{s}, \mathrm{ArCH}_{3}\right), 3.16$ (1H, m, H-3), $3.75(1 \mathrm{H}, \mathrm{d}, J=9.5 \mathrm{~Hz}, \mathrm{H}-28), 4.07(1 \mathrm{H}, \mathrm{d}$, $J=9.2 \mathrm{~Hz}, \mathrm{H}-28), 4.56$ and $4.64\left(2 \mathrm{H}, \mathrm{s},=\mathrm{CH}_{2}\right), 7.36(2 \mathrm{H}$, $\mathrm{d}, J=8.4 \mathrm{~Hz}$, aromatic), $7.81(2 \mathrm{H}, \mathrm{d}, J=8.4 \mathrm{~Hz}$, aromatic); ${ }^{13} \mathrm{C} \mathrm{NMR}\left(\mathrm{CDCl}_{3}, 67.5 \mathrm{MHz}\right): \delta 14.7$ (C-27), 15.3 (C-24), 15.8 (C-26), 16.0 (C-25), 18.2 (C-6), 19.0 (C-30), 20.6 (C-11), $21.6\left(\mathrm{ArCH}_{3}\right), 25.0$ (C-12), 26.5 (C-15), 27.3 (C-2), 27.9 (C-23), 29.1 (C-16), 29.2, 34.1 (C-7 and C-22), 37.1 (C-10), 37.6 (C-13), 38.6 (C-1), 38.8 (C-4), 40.7 (C-8), 42.6 (C-14), 46.7 (C-19), 47.6 (C-17), 48.7 (C-18), 50.2 (C-9), 55.2 (C-5), 69.3 (C-28), 78.9 (C-3), 110.0 (C-29), 128.0, 129.8, 132.9 and 144.7 (aromatic), 149.6 (C-20).

\section{Synthesis of lupeol (6)}

To a solution of tosylate $5(568.0 \mathrm{mg}, 0.928 \mathrm{mmol})$ in $25 \mathrm{~mL}$ of THF, $175.0 \mathrm{mg}$ of $\mathrm{LiAlH}_{4}$ and $48.1 \mathrm{mg}$ of $\mathrm{LiBH}_{4}$ was added. The mixture was allowed to stir at $50-65{ }^{\circ} \mathrm{C}$ for 3 days. The reaction was quenched with sat. $\mathrm{NH}_{4} \mathrm{Cl}$ aq. and the resultant solution was washed with EtOAc. The organic layer was washed with brine, dried over anhydrous $\mathrm{Na}_{2} \mathrm{SO}_{4}$ and evaporated in vacuo. The resulting crude product was subjected to flash silica gel column chromatography eluting with EtOAc:hexane=1:4, followed by concentration of the corresponding fractions in vacuo to afford $109.0 \mathrm{mg}$ of lupeol (28\%). ${ }^{1} \mathrm{H}$ NMR $\left(\mathrm{CDCl}_{3}, 270 \mathrm{MHz}\right): \delta 0.76,0.79,0.83,0.94,0.96$ and 1.03 $(18 \mathrm{H}, \mathrm{s}, \mathrm{H}-23,24,25,26,27$ and 28), 1.68 (3H, s, H-29), $2.37(1 \mathrm{H}, \mathrm{dt}, J=10.9,10.9,5.6 \mathrm{~Hz}, \mathrm{H}-19), 3.18(1 \mathrm{H}, \mathrm{dd}$, $J=10.4,5.5 \mathrm{~Hz}, \mathrm{H}-3), 4.56$ and $4.69\left(2 \mathrm{H}, \mathrm{s},=\mathrm{CH}_{2}\right) ;{ }^{13} \mathrm{C}$ NMR $\left(\mathrm{CDCl}_{3}, 67.5 \mathrm{MHz}\right): \delta 14.5$ (C-27), 15.3 (C-24), 15.9 (C-26), 16.1 (C-25), 18.0 (C-28), 18.3 (C-6), 19.3 (C-30), 20.9 (C-11), 25.1 (C-12), 27.4 (C-15), 27.4 (C-2), 28.0 (C-23), 29.8 (C-21), 34.3 (C-7), 35.5 (C-16), 37.1 (C-10), 38.0 (C-13), 38.7 (C-1), 38.8 (C-4), 40.0 (C-22), 40.8 (C-8), 42.8 (C-14), 42.9 (C-17), 47.9 (C-19), 48.3 (C-18), 50.4 (C-9), 55.3 (C-5), 78.9 (C-3), 109.3 (C-29), 150.8 (C-20).

\section{Synthesis of (3ß)-hydroxy-29-norlupan-20-one (7)}

To a stirred solution of lupeol $(62.5 \mathrm{mg}, 0.146 \mathrm{mmol})$ in $4 \mathrm{~mL}$ of dioxane: $\mathrm{H}_{2} \mathrm{O}(3: 1, \mathrm{v} / \mathrm{v})$ was added $N$-methylmorpholine $N$-oxide $(17.1 \mathrm{mg}, 0.146 \mathrm{mmol})$ and $25 \mu \mathrm{L}$ of $2.5 \%$ $\mathrm{OsO}_{4}$ solution. After 2 days stirring, $62.6 \mathrm{mg}$ of $\mathrm{NaIO}_{4}$ 
Table $1{ }^{1} \mathrm{H}$ and ${ }^{13} \mathrm{C}$ NMR peak lists of isolated compound 1 and predicted ${ }^{13} \mathrm{C}$ chemical shifts of 29-norlupane-3,20-dione and 29-nor-21 aH-hopane-3,22-dione

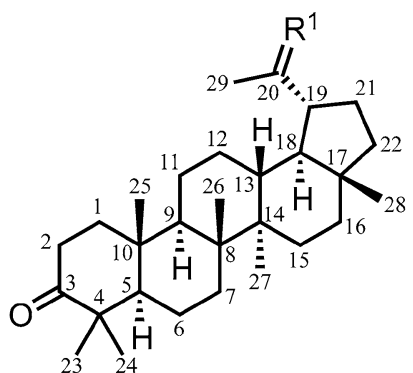

$\mathrm{R}^{1}=\mathrm{O}$ :

29-Norlupan-3,20-dione (Cole et al. [8])

$\mathrm{R}^{1}=\mathrm{CH}_{2}$ : Lupenone

(e.g. Regasa et al. [10])

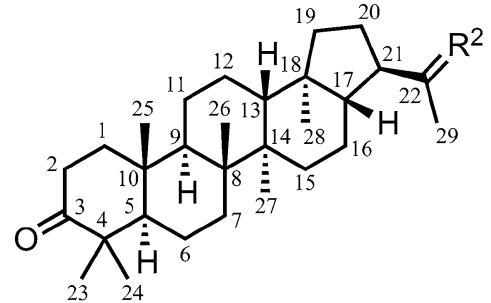

$\mathrm{R}^{2}=\mathrm{O}$ :

29-Nor-21 $\alpha H$-hopane-3,22-dione

(Minh et al. [9])

$\mathrm{R}^{2}=\mathrm{CH}_{2}$ : Moretenone

(e.g. McLean et al. [11])

\begin{tabular}{|c|c|c|c|c|c|}
\hline \multicolumn{2}{|l|}{ Compound 1} & \multicolumn{4}{|c|}{ Calculated ${ }^{13} \mathrm{C}$ shifts $\left(\Delta \delta_{\mathrm{C}}\right.$ between 1$)$} \\
\hline${ }^{1} \mathrm{H}$ & ${ }^{13} \mathrm{C}$ & Position & 29-Norlupan-3,20-dione & Position & $\begin{array}{l}\text { 29-Nor-21aH- } \\
\text { hopane-3,22- } \\
\text { dione }\end{array}$ \\
\hline $1.82-1.90 \mathrm{~m}$ and * & 39.5 & 1 & $40.4(-0.9)$ & 1 & $39.9(-0.4)$ \\
\hline $2.45 \mathrm{~m}$ & 34.1 & 2 & $33.0(1.1)$ & 2 & $33.1(1.0)$ \\
\hline- & 218.2 & 3 & $214.9(3.3)$ & 3 & $215.0(3.2)$ \\
\hline- & 47.3 & 4 & $47.2(0.1)$ & 4 & $47.2(0.1)$ \\
\hline * & 54.8 & 5 & $53.3(1.5)$ & 5 & $52.6(2.2)$ \\
\hline * & 19.7 & 6 & $20.8(-1.1)$ & 6 & $20.9(-1.2)$ \\
\hline * & 33.5 & 7 & $33.8(-0.3)$ & 7 & $31.7(1.8)$ \\
\hline- & 40.8 & 8 & $40.8(0.0)$ & 8 & $42.0(-1.2)$ \\
\hline * & 49.6 & 9 & $50.0(-0.4)$ & 9 & $49.5(0.1)$ \\
\hline- & 36.9 & 10 & $36.7(0.2)$ & 10 & $36.9(0.0)$ \\
\hline * & 21.5 & 11 & $22.3(-0.8)$ & 11 & $21.5(0.0)$ \\
\hline $2.02-2.10 \mathrm{~m}$ and * & 27.2 & 12 & $26.9(0.3)$ & 12 & $23.8(3.4)$ \\
\hline $1.58-1.69 \mathrm{~m}$ & 37.1 & 13 & $36.8(0.3)$ & 13 & $47.2(-10.1)$ \\
\hline- & 42.7 & 14 & $43.3(-0.6)$ & 14 & $42.3(0.4)$ \\
\hline $1.58-1.69 \mathrm{~m}$ and * & 27.3 & 15 & $28.1(-0.8)$ & 15 & $32.3(-5.0)$ \\
\hline$*$ & 34.9 & 16 & $34.5(0.4)$ & 16 & $21.9(13.0)$ \\
\hline- & 43.0 & 17 & $42.4(0.6)$ & 18 & $44.4(-1.4)$ \\
\hline $1.84 \mathrm{t}$ & 49.5 & 18 & $47.9(1.6)$ & 17 & $52.3(-2.8)$ \\
\hline $2.59 \mathrm{dt}$ & 52.6 & 19 & $51.9(0.7)$ & 21 & $52.5(0.1)$ \\
\hline- & 212.9 & 20 & 209.5 (3.4) & 22 & $209.5(3.4)$ \\
\hline $2.02-2.10 \mathrm{~m}$ and * & 27.7 & 21 & $27.9(-0.2)$ & 20 & $26.6(1.1)$ \\
\hline$*$ & 39.8 & 22 & $39.7(0.1)$ & 19 & $39.8(0.0)$ \\
\hline $1.03 \mathrm{~s}$ & 21.0 & 23 & $21.1(-0.1)$ & 23 & $21.1(-0.1)$ \\
\hline $1.07 \mathrm{~s}$ & 26.7 & 24 & $26.5(0.2)$ & 24 & $26.5(0.2)$ \\
\hline $0.92 \mathrm{~s}$ & 16.0 & 25 & $18.7(-2.7)$ & 25 & $17.7(-1.7)$ \\
\hline $1.06 \mathrm{~s}$ & 15.7 & 26 & $17.2(-1.5)$ & 26 & $17.7(-2.0)$ \\
\hline $0.98 \mathrm{~s}$ & 14.4 & 27 & $15.3(-0.9)$ & 27 & $18.8(-4.4)$ \\
\hline $0.79 \mathrm{~s}$ & 18.0 & 28 & $18.5(-0.5)$ & 28 & $15.9(2.1)$ \\
\hline $2.16 \mathrm{~s}$ & 29.2 & 29 & $28.3(0.9)$ & 29 & $29.6(-0.4)$ \\
\hline
\end{tabular}

* 1.03-1.54 ppm 
(0.293 mmol) was added. When the reaction completed, sat. $\mathrm{Na}_{2} \mathrm{SO}_{3}$ aq. was added to the mixture followed by extraction with $\mathrm{Et}_{2} \mathrm{O}$. The organic layer was dried over anhydrous $\mathrm{Na}_{2} \mathrm{SO}_{4}$ and evaporated in vacuo. The resulting crude product was purified by flash silica gel column chromatography eluting with EtOAc:hexane $=2: 5$ to give $43.9 \mathrm{mg}$ of (3ß)-hydroxy-30-norlupan-20-one (71\%). ${ }^{1} \mathrm{H} \mathrm{NMR}\left(\mathrm{CDCl}_{3}, 270 \mathrm{MHz}\right): \delta$ 0.76, 0.77, 0.83, 0.97 and $1.02(18 \mathrm{H}, \mathrm{s}, \mathrm{H}-23,24,25,26,27$ and 28), 1.82 $(1 \mathrm{H}, \mathrm{t}, J=11.3 \mathrm{~Hz}, \mathrm{H}-18), 2.05(1 \mathrm{H}, \mathrm{m}, \mathrm{H}-21), 2.15$ (3H, s, $\mathrm{H}-29), 2.58(1 \mathrm{H}, \mathrm{dt}, J=11.2,11.2,5.7 \mathrm{~Hz}, \mathrm{H}-19), 3.19(1 \mathrm{H}$, $\mathrm{dd}, J=10.7,5.0 \mathrm{~Hz}, \mathrm{H}-3) ;{ }^{13} \mathrm{C} \mathrm{NMR}\left(\mathrm{CDCl}_{3}, 67.5 \mathrm{MHz}\right)$ : $\delta$ 14.4 (C-27), 15.4 (C-24), 15.9 (C-26), 16.0 (C-25), 17.9 (C-28), 18.3 (C-6), 20.9 (C-11), 27.1 (C-12), 27.3 (C-2 and C-15), 27.6 (C-21), 28.0 (C-23), 29.1 (C-29), 34.2 (C-7), 34.9 (C-16), 37.0 (C-13), 37.1 (C-10), 38.6 (C-1), 38.8 (C-4), 39.8 (C-22), 40.7 (C-8), 42.6 (C-17), 43.0 (C-14), 49.6 (C-18), 50.2 (C-9), 52.6 (C-19), 55.2 (C-5), 78.8 (C-3), 212.9 (C-20).

\section{Synthesis of 29-norlupan-3,20-dione}

To a stirred solution of 7 (43.9 $\mathrm{mg}, 0.103 \mathrm{mmol})$ in $7 \mathrm{~mL}$ of $\mathrm{CH}_{2} \mathrm{Cl}_{2}$ was added $87.4 \mathrm{mg}$ of Dess-Martin periodinane $(0.206 \mathrm{mmol})$. After $1 \mathrm{~h}$, the mixture was partitioned between sat. $\mathrm{NaHCO}_{3}$ aq. solution and $\mathrm{CHCl}_{3}$, and the organic layer was washed with brine. The organic layer was dried over anhydrous $\mathrm{Na}_{2} \mathrm{SO}_{4}$ and evaporated in vacuo. The resulting crude product was purified with flash silica gel column chromatography eluting with EtOAc:hexane $=1: 2$ to give $36.9 \mathrm{mg}$ of 29-norlupan3,20-dione (84\%). $[\alpha]_{\mathrm{D}}^{25}+20.4\left(\right.$ c 1.23, $\left.\mathrm{CHCl}_{3}\right)$; ${ }^{1} \mathrm{H}$ NMR $\left(\mathrm{CDCl}_{3}, 270 \mathrm{MHz}\right): \delta 0.79,0.92,0.98,1.03,1.06$ and $1.07(18 \mathrm{H}, \mathrm{s}, \mathrm{H}-23,24,25,26,27$ and 28$), 1.84(1 \mathrm{H}, \mathrm{t}$, $J=11.5 \mathrm{~Hz}, \mathrm{H}-18), 1.84-2.15$ (4H, m, H-1b, H-12 and H-21b), 2.15 (3H, s, H-29), 2.37-2.49 (2H, m, H-2), 2.59 $(1 \mathrm{H}, \mathrm{dt}, J=11.2,11.2,5.8 \mathrm{~Hz}, \mathrm{H}-19) ;{ }^{13} \mathrm{C} \mathrm{NMR}\left(\mathrm{CDCl}_{3}\right.$, $67.5 \mathrm{MHz}$ ): $\delta$ 14.4 (C-27), 15.7 (C-26), 15.9 (C-25), 18.0 (C-28), 19.6 (C-6), 21.0 (C-23), 21.4 (C-11), 26.7(C-24), 27.2 (C-12), 27.3 (C-15), 27.6 (C-21), 29.2 (C-29), 33.4 (C-7), 34.1 (C-2), 34.9 (C-16), 36.8(C-10), 37.1 (C-13), 39.5 (C-1), 39.8 (C-22), 40.6 (C-8), 42.7 (C-14), 43.0 (C-17), 47.2 (C-4), 49.5 (C-18), 49.6 (C-9), 52.5 (C-19), 54.8 (C-5), 212.7 (C-20), 218.1 (C-3).

\section{Synthesis of oleanolic acid acetate}

To a solution of $106.4 \mathrm{mg}$ of oleanolic acid $(0.219 \mathrm{mmol})$ in $4.0 \mathrm{~mL}$ of pyridine, $413 \mu \mathrm{L}$ of acetic anhydride and $80.7 \mathrm{mg}$ of $N, N$-dimethyl-4-aminopyridine were added. After $2 \mathrm{~h}$ stirring, the mixture was partitioned between $0.5 \mathrm{M} \mathrm{HCl}$ aq. and EtOAc. The organic layer was washed with sat. $\mathrm{NaHCO}_{3}$ aq. and brine. After drying over anhydrous $\mathrm{Na}_{2} \mathrm{SO}_{4}$ and subsequent evaporation, the crude product was purified by flash silica gel column chromatography eluting with EtOAc:hexane $=1: 4$ to give $101.8 \mathrm{mg}$ of oleanolic acid acetate (93\%).

\section{Synthesis of ursolic acid acetate}

Following the same procedure described above, $17.5 \mathrm{mg}$ of ursolic acid acetate was prepared from $15.6 \mathrm{mg}$ of ursolic acid in quantitative yield. Flash silica gel column chromatography was performed with $\mathrm{MeOH}: \mathrm{CHCl}_{3}=5: 95$.

\section{Results and discussion \\ Isolation of anti-toxoplasma compounds from Quercus crispula Blume outer bark}

To explore novel anti-toxoplasma natural products, the activities of methanolic bark extracts from northern tree species were evaluated. The anti-toxoplasma assay was performed based on ELISA quantifying microneme 10 (MIC10) protein [6]. MIC10 protein is secreted by toxoplasma when invading a host cell and has key actions in invasion and proliferation of the parasite. Therefore, the quantity of MIC10 can reflect the growth of T. gondii. Among tested 14 bark extracts, only an outer bark extract from Quercus crispula Blume (mizunara) showed complete inhibition at $10 \mu \mathrm{g} / \mathrm{mL}$ whereas others did not exhibited any activity (data not shown). To identify the active compound(s) from Mizunara outer bark extract, next a bioassayguided isolation was undertaken. The bark extract was prepared with $\mathrm{CHCl}_{3}$, which can extract equal titer of active ingredients to previously used methanol. The extract was subjected to flash silica gel column chromatography with eluting EtOAc:hexane $=1: 9$ to $1: 7$ and then EtOAc:hexane $=1: 10$ to $1: 7$. Obtained active fraction was purified with reverse phase HPLC. As shown in Fig. 1a, three major peaks were detected and a following bioassay revealed that they all show anti-toxoplasma activities, whereas other regions showed no activity. The first peak at RT 9.62 min was identified as the mixture of pentadecanoic acid and bis-unsaturated C18 fatty acid by EI mass spectrometry (MS) coupled with NIST library search. Although this mixture showed same activity as fractions later discussed, further investigation was not made due to its low yield (3.4\%) and the possibility as contaminants. The second peak at RT 12.15 was isolated as pure compound $\mathbf{1}$. The third peak at RT 13.25 was also fractionated, but the fraction was still a binary mixture. As they could not be separated under any conditions tested (e.g., use of acetonitrile, normal phase or HILIC mode), recycle HPLC separation was applied. The third fraction was subjected to ODS HPLC and the eluate was recycled 8 times in the system, which resulted in a successful isolation of two active compounds 2 and $\mathbf{3}$ (Fig. 1b). 
Table $2{ }^{1} \mathrm{H}$ and ${ }^{13} \mathrm{C}$ NMR peak lists and signal assignments of isolated compounds 2 and 3

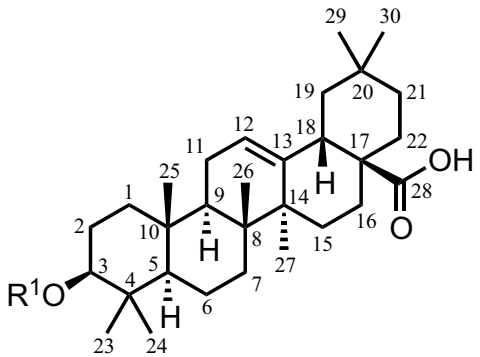

$\mathrm{R}^{1}=\mathrm{Ac}:$ Oleanolic acid acetate (2)

$\mathrm{R}^{1}=\mathrm{H}: \quad$ Oleanolic acid $(\mathbf{8})$

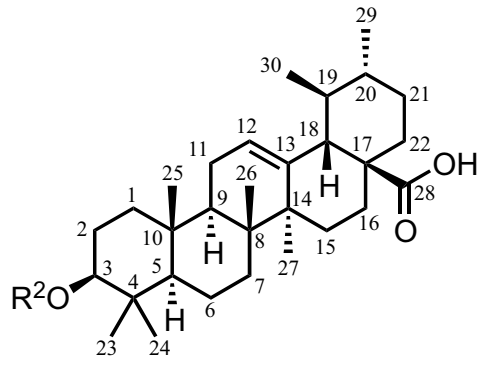

$\mathrm{R}^{2}=\mathrm{Ac}$ : Ursolic acid acetate (3)

$\mathrm{R}^{2}=\mathrm{H}: \quad$ Ursolic acid (9)

\begin{tabular}{|c|c|c|c|c|}
\hline \multirow[b]{2}{*}{ Position } & \multicolumn{2}{|l|}{ Compound 2} & \multicolumn{2}{|l|}{ Compound 3} \\
\hline & ${ }^{1} \mathrm{H}$ & ${ }^{13} \mathrm{C}$ & ${ }^{1} \mathrm{H}$ & ${ }^{13} \mathrm{C}$ \\
\hline 1 & $*$ and $* * *$ & 38.1 & t and t+† & 38.3 \\
\hline 2 & *** and $1.87-1.90 \mathrm{~m}$ & 23.5 & $\neq$ and $\neq \neq$ & 23.6 \\
\hline 3 & $4.49 \mathrm{~m}$ & 80.9 & $4.50 \mathrm{dd}(J=9.8,6.3 \mathrm{~Hz})$ & 80.9 \\
\hline 4 & - & 37.7 & - & 37.7 \\
\hline 5 & $0.83-0.88 m$ & 55.3 & $0.82-0.91 \mathrm{~m}$ & 55.2 \\
\hline 6 & ${ }^{* *}$ and ${ }^{* * *}$ & 18.2 & †† and +†† & 18.2 \\
\hline 7 & $* *$ & 32.6 & t† and t†† & 32.8 \\
\hline 8 & - & 39.3 & - & 39.5 \\
\hline 9 & $* * *$ & 47.6 & t†t & 47.5 \\
\hline 10 & - & 37.0 & - & 36.9 \\
\hline 11 & ${ }^{* * *}$ and $1.87-1.90 \mathrm{~m}$ & 23.4 & $\neq$ and $\neq \neq$ & 23.3 \\
\hline 12 & $5.28 \mathrm{t}(J=3.5 \mathrm{~Hz})$ & 122.6 & $5.24 \mathrm{t}(J=3.5 \mathrm{~Hz})$ & 125.7 \\
\hline 13 & - & 143.6 & - & 138.0 \\
\hline 14 & - & 41.6 & - & 41.9 \\
\hline 15 & ${ }^{*}$ and ${ }^{* * *}$ & 27.7 & † and 㧊 & 28.0 \\
\hline 16 & ** and $1.99 \mathrm{dt}(J=13.6,13.6,3.9 \mathrm{~Hz})$ & 22.9 & $\neq \neq$ and $2.01 \mathrm{dt}(J=13.5,13.5,4.0 \mathrm{~Hz})$ & 24.1 \\
\hline 17 & - & 46.5 & - & 48.0 \\
\hline 18 & $2.82 \mathrm{dd}(J=13.6,4.1 \mathrm{~Hz})$ & 41.0 & $2.18 \mathrm{~d}(J=11.2 \mathrm{~Hz})$ & 52.5 \\
\hline 19 & $*$ and ${ }^{* * *}$ & 45.9 & t† & 39.0 \\
\hline 20 & - & 30.7 & t† & 38.8 \\
\hline 21 & $* *$ & 33.8 & †† and t†† & 30.6 \\
\hline 22 & $* * *$ & 32.4 & $\neq$ & 36.7 \\
\hline 23 & $0.85 \mathrm{~s}$ & 16.7 & $0.85 \mathrm{~s}$ & 16.7 \\
\hline 24 & $0.87 \mathrm{~s}$ & 28.0 & $0.87 \mathrm{~s}$ & 28.1 \\
\hline 25 & $0.94 \mathrm{~s}$ & 15.4 & $0.96 \mathrm{~s}$ & 15.5 \\
\hline 26 & $0.76 \mathrm{~s}$ & 17.1 & $0.77 \mathrm{~s}$ & 17.0 \\
\hline 27 & $1.13 \mathrm{~s}$ & 25.9 & $1.07 \mathrm{~s}$ & 23.6 \\
\hline 28 & - & 182.7 & - & 183.5 \\
\hline 29 & $0.93 \mathrm{~s}$ & 23.6 & $0.86 \mathrm{~d}(J=5.6 \mathrm{~Hz})$ & 17.1 \\
\hline 30 & $0.91 \mathrm{~s}$ & 33.1 & $0.95 \mathrm{~d}(J=6.3 \mathrm{~Hz})$ & 21.2 \\
\hline acetyl $\mathrm{CH}_{3}$ & $2.05 \mathrm{~s}$ & 21.3 & $2.05 \mathrm{~s}$ & 21.3 \\
\hline acetyl $C=0$ & - & 171.0 & - & 171.1 \\
\hline
\end{tabular}

*1.00-1.13 ppm; ** 1.17-1.48 ppm; *** 1.52-1.81 ppm

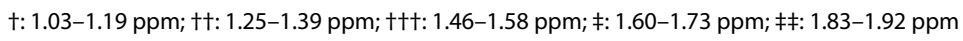



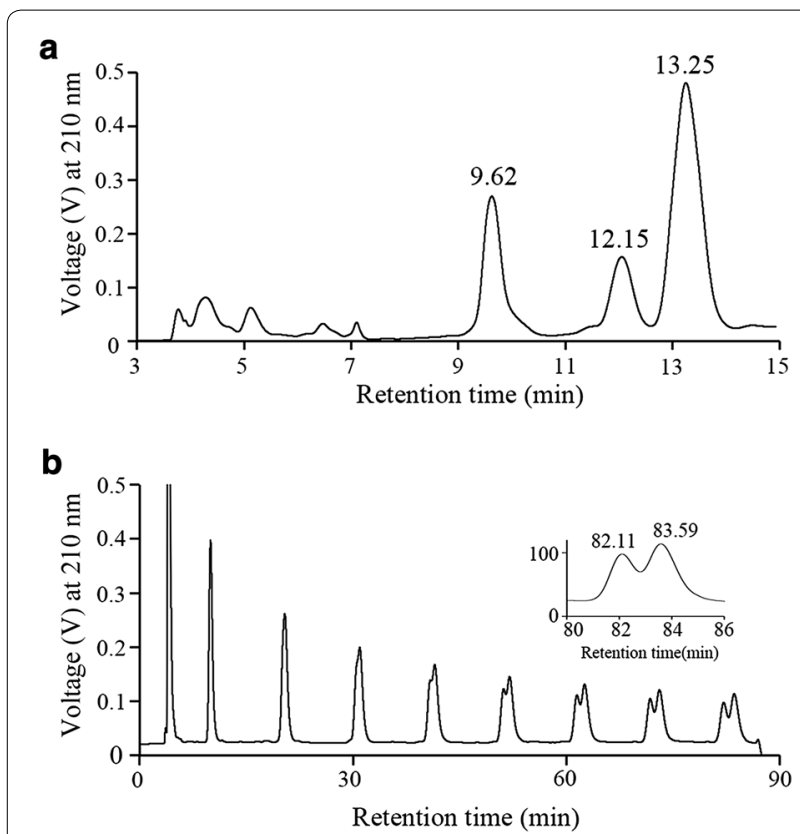

Fig. 1 HPLC chromatogram of a active fraction obtained from Quercus crispula Blume outer bark extract; $\mathbf{b}$ recycle-valve separation of two-component mixture (peak at $13.25 \mathrm{~min}$ in $\mathbf{a}$ )

\section{Structure elucidation of isolated compounds 1, 2 and 3}

The structures of isolated compounds were elucidated on the basis of NMR, specific rotation, MS analyses and the comparison with reported data. Two partial structures of compound $\mathbf{1}$ were successfully deduced from ${ }^{1} \mathrm{H},{ }^{13} \mathrm{C}$, COSY, HSQC and HMBC NMR spectra, and the molecular formula was determined as $\mathrm{C}_{29} \mathrm{H}_{46} \mathrm{O}_{2}$ from MS. Although these results suggested two candidate structures, 29-norlupane-3,20-dione [8] and 29-nor$21 \alpha H$-hopane-3,22-dione [9], it could not be concluded because both NMR data were highly consistent with compound $1\left(\Delta \delta_{\mathrm{C}}<0.2 \mathrm{ppm}\right)$. However, this coincidence in two reported structures is unlikely to occur given the differences between lupenone [10] and moretenone [11], the structurally scrutinized analogs of the above two compounds. Lupenone and moretenone have the same ring system, substituent position and steric configuration as 29-norlupane-3,20-dione and 29-nor-21 $\alpha H$-hopane3,22-dione, respectively (Table 1 ). Meanwhile, their chemical shifts in ${ }^{13} \mathrm{C}$ NMR are clearly distinguishable especially in D- and E-ring $\left(\Delta \delta_{C}=2.5-14.7 \mathrm{ppm}\right)$. These differences are significant enough to exclude a coincidence in chemical shifts of 29-norlupane-3,20-dione and 29-nor-21 $\alpha H$-hopane-3,22-dione. Thus, we next synthesized 29-norlupane-3,20-dione as a reference compound from structurally reliable lup-20(29)-ene-3ß,28-diol, also known as betulin (4). As depicted in Scheme 1, a hydroxyl group at C-28 was first tosylated and reduced to give lupeol (6). The double bond at C-20(29) was converted to carbonyl group under $\mathrm{OsO}_{4} / \mathrm{NaIO}_{4}$ conditions to give compound 7 and the $3-\mathrm{OH}$ group was oxidized to ketone to form 29-norlupane-3,20-dione. The spectral data of synthesized 29-norlupane-3,20-dione were highly consistent with those of isolated compound $\mathbf{1}$ $\left(\Delta \delta_{C}<0.2 \mathrm{ppm}\right)$ showing the same positive specific rotation. Thus, the identity between compound $\mathbf{1}$ and 29-norlupane-3,20-dione was demonstrated. On the other hand, 29-nor-21 $\alpha H$-hopane-3,22-dione clearly conflicts with compound $\mathbf{1}$ in consideration of NMR chemical shift difference between the following synthetic intermediates. In the synthesis, the conversion of C-20(29) double bond to
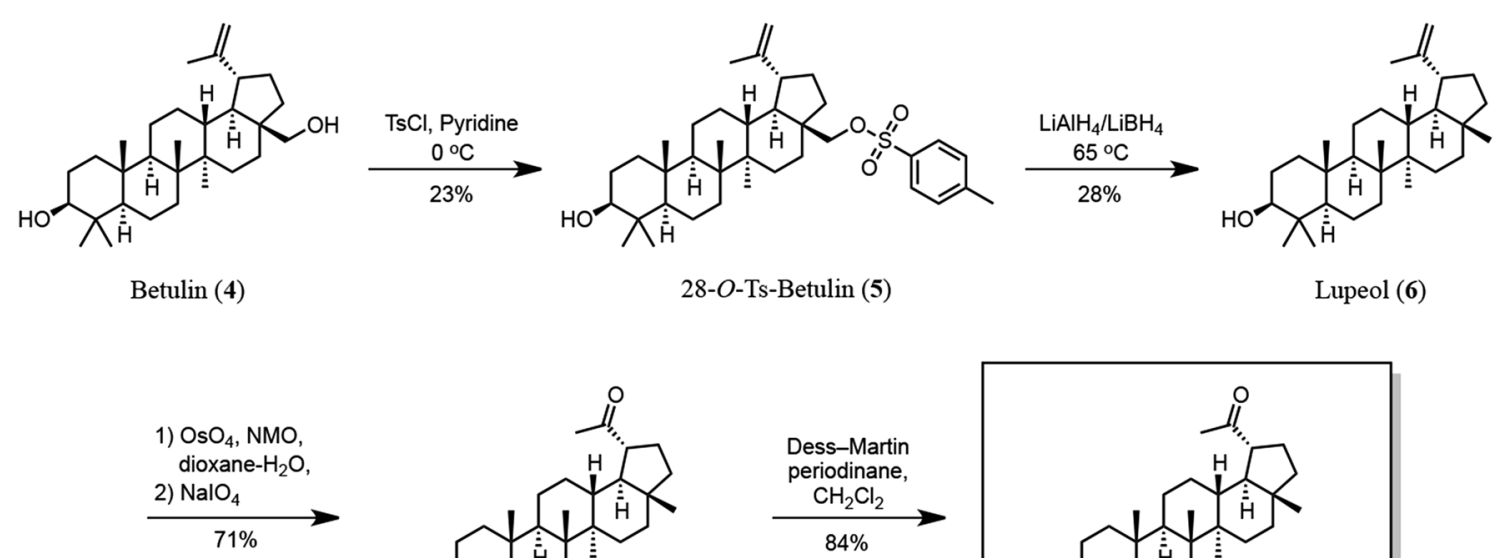

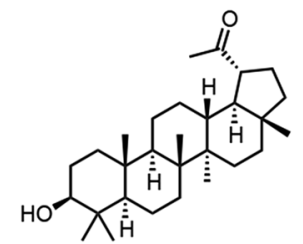

(3ß)-Hydroxy-29-norlupan-20-one (7)

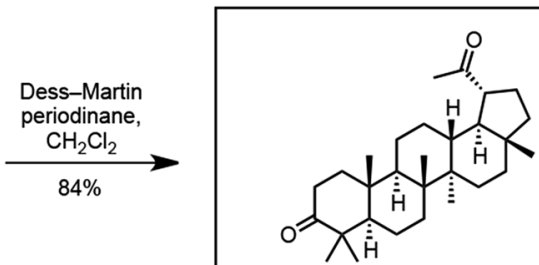

29-Norlupan-3,20-dione (1)

Scheme 1 Synthesis of 29-norlupan-3,20-dione 
carbonyl group (6 to 7) resulted in lower field shift at C-19 by $4.5 \mathrm{ppm}$, with affecting the shifts of surrounding C-18 and C-21 $\left(\Delta \delta_{C}:+4.5\right.$ and $-2.2 \mathrm{ppm}$, respectively). Meanwhile, if the same conversion was made for moretenone (giving Minh's 29-nor-21 $\alpha H$-hopane-3,22-dione), the signal of C-21 is considered to shift by around $10.7 \mathrm{ppm}$ higher field without affecting $\mathrm{C}-20\left(\Delta \delta_{\mathrm{C}}: \pm 0 \mathrm{ppm}\right)$. Despite being in distant locations, C-15, C-16 and C-28 are also considered to shift by $0.8-6.9 \mathrm{ppm}$. Thus, the possibility of compound 1 to be 29-nor-21 $\alpha H$-hopane3,22-dione can be excluded. The results of computational prediction for ${ }^{13} \mathrm{C}$ NMR also supported this prospect as indicated in Table 1 . The density functional theory-based calculations coupled with Boltzman weight calibration were applied for both compounds and the results were compared with experimental spectrum [7]. The predicted ${ }^{13} \mathrm{C}$ chemical shifts of 29-norlupane-3,20-dione showed satisfactory matches $\left(\Delta \delta_{\mathrm{C}}<1.6 \mathrm{ppm}\right.$ except C-3, C-20 and $\mathrm{C}-25)$ with compound 1 . In contrast, many indispensable differences were observed in the case of 29 -nor-21 $\alpha \mathrm{H}$ hopane-3,22-dione, such in C-12, C-13, C-15, C-16, and C-27 $\left(\Delta \delta_{C}=3.4-13.0 \mathrm{ppm}\right)$ even after the reassignment of shift values to minimize deviations. From these observations, here we concluded that compound 1 is 29 -norlupane-3,20-dione not 29-nor-21 $\alpha H$-hopane-3,22-dione. The spectral data reported by Minh et al. indicate that their isolated compound is 29-norlupane-3,20-dione [9].

The structures of compounds $\mathbf{2}$ and $\mathbf{3}$ were identified as acetates of oleanolic acid [12, 13] and ursolic acid [14], respectively. The chemical shifts of ${ }^{1} \mathrm{H}$ and ${ }^{13} \mathrm{C}$ NMR spectra were all in good agreement with the reported values (Table 2). The relative configuration of each was determined based on NOESY, and the absolute configuration was established from the positive specific rotation to be identical with reported one. In addition, authentic samples corresponding to $\mathbf{2}$ and $\mathbf{3}$ were prepared from commercially available oleanolic acid (8) and ursolic acid (9). The agreements between the spectral data of the isolated compounds and those of the synthetic compounds confirmed the accuracy of structure elucidation. The qualitative GC-MS analysis of the methanolic extract was performed to verify the possibility of two acetates being artifacts arisen from isolation procedures (Fig. 2). Interestingly, both acetates (2 and $\mathbf{3})$ and alcohols ( $\mathbf{8}$ and 9) could be observed in original extract. The result evidenced that $\mathbf{2}$ and $\mathbf{3}$ were naturally occurring in the bark. To date there has been no report on the biological activity of 29-norlupane-3,20-dione and the anti-toxoplasma activity of oleanolic acid acetate and ursolic acid acetate. The present study first unveiled novel activity of these compounds.

\section{Anti-toxoplasma activities of isolated compounds and structure-activity relationship study}

The anti-toxoplasma activities of isolated compounds 1-3 were determined as $\mathrm{IC}_{50}$ using the in vitro growth assay of T. gondii [6] as shown in Table 3. Cytotoxicity against human foreskin fibroblast (HFF) cells was tested and the selective toxicity to parasites was shown as selectivity index (SI), the ratio of $\mathrm{IC}_{50}$ for the host divided by $\mathrm{IC}_{50}$ for $T$. gondii. Interestingly, isolated compounds 1-3 showed $\mathrm{IC}_{50}$ of $6.8-24.4 \mu \mathrm{M}$ against the parasite, whereas tenfold higher concentrations were required against the host cell $(68.0-375.9 \mu \mathrm{M})$. The isolated compounds exhibited superior activities over maslinic acid, a known anti-toxoplasma triterpenoid whose $\mathrm{IC}_{50}$ and $\mathrm{SI}$ were $53.81 \pm 1.4 \mu \mathrm{M}$ and 4.4, respectively [15]. The results demonstrated that the isolated compounds could be specific anti-toxoplasma agents or promising lead compounds for developing novel drugs.

To identify key structure(s) for activity and selectivity, the next structure-activity relationship study was conducted using analogs of the isolated compounds. Results are presented in Table 3 as $\mathrm{IC}_{50}$ values. Betulin (4) exhibited potent activity with $\mathrm{IC}_{50}$ of $18.3 \mu \mathrm{M}$, but was more toxic to host cells $(\mathrm{SI}=0.3)$. Oleanolic acid (8) and ursolic acid (9) showed similar activity to their acetates ( 2 and 3 ) but selective toxicities against T. gondii were impaired ( $\mathrm{SI}=1.8$ and 1.2). Synthetic (3ß)-hydroxy-30-norlupan-20-one (7) as an analog of 29-norlupane-3,20-dione did not show inhibitory activity against $T$. gondii and host cells even at $1.0 \mathrm{mM}$. From the comparison between $\mathbf{1}$ and $\mathbf{3}$ and their analogs, it could be concluded that the presence of C-3 hydroxyl group decreases the selectivity against $T$. gondii whereas acetylation or oxidation to carbonyl enables lowering toxicity against host cells. Capping or oxidizing free hydroxyl group at C-3 would elevate the anti-toxoplasma activity itself, as clearly seen in the comparison between $\mathbf{1}$ and 7 , or $\mathbf{2}$ and $\mathbf{8}$. The inferior activity and selectivity of maslinic acid follow these trends. On the other hand, ursolic acid (9) exceptionally retains high anti-toxoplasma activity regardless of its free 3-hydroxyl group, while the selective toxicity of $\mathbf{9}$ was comparable to $\mathbf{8}$. Non-selective toxicities of $\mathbf{9}$ and maslinic acid suggest that inhibitory activity against protease might correlate with non-selective toxicities of these oleananes [15]. Functionalities around E-ring seem to have a crucial impact on activity, as observed in the case of betulin (4) that shows potent activity despite its structural analogy to inactive compound 7 . Although stringent comparison is difficult with the present compounds, high polar functionality, such as carboxyl or hydroxyl group on E-ring, might contribute to 


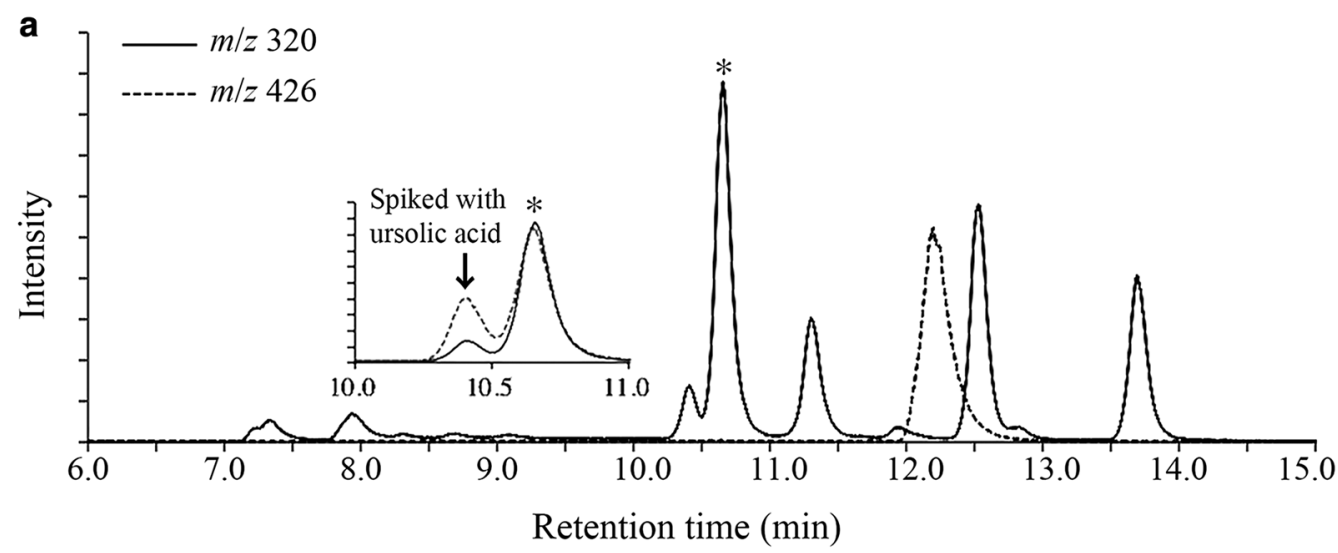

b

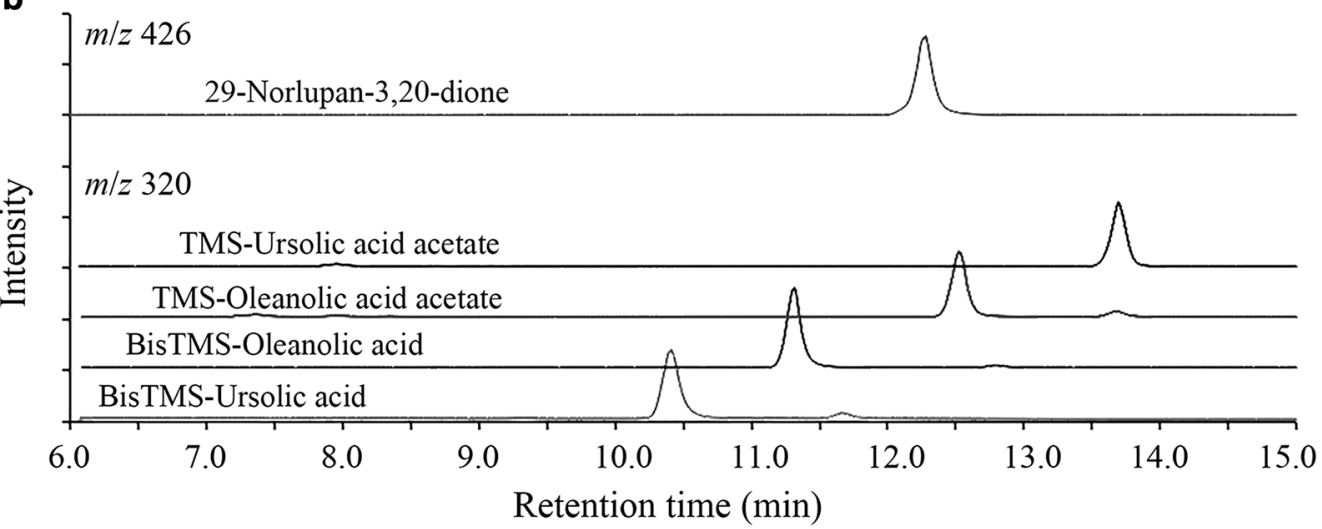

Fig. 2 Qualitative GC-MS chromatogram of a TMS-derivatized methanolic extract from Q. crispula Blume outer bark; b TMS-derivatized authentic compounds. *Unidentified triterpenoid-like compound

Table 3 Anti-toxoplasma activities of isolated compounds 1-3 and their analogs

\begin{tabular}{|c|c|c|c|}
\hline Compounds & T. gondii inhibition ( $\mathrm{IC}_{50}$ ) & HFF cytotoxicity ${ }^{\mathrm{a}}\left(\mathrm{IC}_{50}\right)$ & $\begin{array}{l}\text { Selectivity } \\
\text { index }\end{array}$ \\
\hline Isolated & & & 15.4 \\
\hline 29-Norlupan -3,20-dione (I) & $24.4 \pm 1.5$ & $375.9 \pm 95.9$ & 10.0 \\
\hline Oleanolic acid acetate (2) & $6.8 \pm 0.8$ & $68.0 \pm 2.2$ & 12.1 \\
\hline Ursolic acid acetate $\mathbf{( 3 )}$ & $7.9 \pm 0.4$ & $95.6 \pm 6.8$ & \\
\hline \multicolumn{4}{|l|}{ Analogs } \\
\hline Betulin (4) & $18.3 \pm 0.4$ & $4.7 \pm 6.8$ & 0.3 \\
\hline (3ß)-Hydroxy-29 -norlupan-20-one (7) & $>1000$ & $>1000$ & - \\
\hline Oleanolic acid $(\mathbf{8})$ & $54.8 \pm 1.1$ & $96.4 \pm 4.8$ & 1.8 \\
\hline Ursolic acid (9) & $5.9 \pm 0.1$ & $6.4 \pm 0.1$ & 1.1 \\
\hline & $53.81 \pm 1.4$ & $236.61 \pm 6.4^{b}$ & 4.4 \\
\hline Maslinic acid ${ }^{15)}$ & & & \\
\hline
\end{tabular}

Results are given as the mean \pm SD. $(n=3)$

a Human foreskin fibroblasts

b Vero cells were used instead of HFF

c Selectivity Index $=\mathrm{IC}_{50}$ of host cells $/ \mathrm{IC}_{50}$ of $T$. gondii inhibition 
notable activities of 2, 3, 4 and 8. Blockage of gliding motility of $T$. gondii tachyzoites was observed by treating with maslinic acid. One of the action mechanisms of maslinic acid may exert on the tachyzoites in their interaction with the host cell via protease. Maslinic acid and other protease inhibitors cause cytopathological effects on intra- and extracellular forms of the parasite, too [15]. Compound $\mathbf{8}$ is 2-deoxy analog of maslinic acid, thus it might have the same molecular target as maslinic acid. The isolated compounds $\mathbf{1}, \mathbf{2}$, and $\mathbf{3}$ may have different mode of action due to their higher selective indexes in comparison with maslinic acid and $\mathbf{8}$. The findings from this structure-activity relationship study would be highly beneficial for the development of new anti-toxoplasma drugs with high efficacy and high selectivity. In addition, derivatization of betulin, the most abundant extract in Betula platyphylla outer bark, could quantitatively provide such useful drug candidates.

\section{Conclusion}

The authors discovered three potent anti-toxoplasma agents, namely 29-norlupane-3,20-dione (1), oleanolic acid acetate (2) and ursolic acid acetate (3) from the outer bark extract of mizunara. Anti-toxoplasma activity and selective toxicity of these compounds against T. gondii were outstanding compared to other pentacyclic triterpenoids. The structure-activity relationship study has shown that the presence of the carbonyl group on E-ring and modification of 3-hydroxy group is important for potent activity expression and selectivity. The results opened the door for the novel utilization of analogous triterpenoids obtained from natural resources like wood barks.

\section{Abbreviations \\ Ac: acetyl; COSY: correlation spectroscopy; DF: density functional; DMSO: dimethyl sulfoxide; El: electron ionization; ELISA: enzyme-linked immunosorb- ent assay; EtOAc: ethyl acetate; FD: field desorption; Fl: field ionization; GC: gas chromatography; HFF: human foreskin fibroblast; HILIC: hydrophilic interaction chromatography; HMBC: heteronuclear multiple bond coherence; HPLC: high-performance liquid chromatography; HR: high resolution; HSQC: hetero- nuclear single quantum coherence; $I C_{50}$ : half maximal inhibitory concentra- tion; MIC10: microneme 10; MMFF: Merck molecular force field; MS: mass spectrometry; NIST: National Institute of Standards and Technology; NMO: $\mathrm{N}$-methylmorpholine $\mathrm{N}$-oxide; NMR: nuclear magnetic resonance; NOESY: nuclear Overhauser effect spectroscopy; ODS: octadecylsilyl; $R_{f}$ : retardation factor; RT: retention time; SI: selectivity index; THF: tetrahydrofuran; tlc: thin- layer chromatography; TMS: trimethylsilyl; Ts: $p$-toluenesulfonyl.}

\section{Authors' contributions}

$\mathrm{KS}, \mathrm{SM}$ and $\mathrm{MU}$ conceived and planned the experiments. ME, KS and MI carried out the experiment. KS wrote the manuscript with support from MI and MU. KS and MU supervised the project. All authors read and approved the final manuscript.

\begin{abstract}
Author details
1 Division of Applied Bioscience, Graduate School of Agriculture, Hokkaido University, N9 W9, Sapporo 060-8589, Japan. ${ }^{2}$ Department of Cellular and Molecular Biology, The University of Texas Health Science Center at Tyler, Tyler, TX 75708, USA. ${ }^{3}$ National Research Center for Protozoan Diseases, Obihiro University of Agriculture and Veterinary Medicine, Inada, Obihiro, Hokkaido 080-8555, Japan.
\end{abstract}

\section{Acknowledgements}

This research was supported by Cooperative Research Grant of National Research Center for Protozoan Diseases, Obihiro University of Agriculture and Veterinary Medicine. The authors also express gratitude to Field Science Center for Northern Biosphere, Hokkaido University for the assistance of sample collection.

\section{Competing interests}

The authors declare that they have no competing interests.

\section{Availability of data and materials}

All data generated or analyzed during this study are included in this published article. The spectral data of NMR are available from the corresponding author on reasonable request.

\section{Funding}

Cooperative Research Grant (27-joint-1) of National Research Center for Protozoan Diseases, Obihiro University of Agriculture and Veterinary Medicine.

\section{Publisher's Note}

Springer Nature remains neutral with regard to jurisdictional claims in published maps and institutional affiliations.

Received: 26 September 2018 Accepted: 18 January 2019

Published online: 08 February 2019

\section{References}

1. Dubey JP (2009) Toxoplasmosis in animals and humans, 2nd edn. CRC Press, Boca Raton

2. Cook AJ, Gilbert RE, Buffolano W, Zufferey J, Petersen E, Jenum PA, Foulon W, Semprini AE, Dunn DT (2000) Sources of Toxoplasma infection in pregnant women: European multicentre case-control study. European Research Network on Congenital Toxoplasmosis. BMJ 321:142-147

3. Centers for Disease Control and Prevention (2017) Parasites-Neglected Parasitic Infections(NPIs). https://www.cdc.gov/parasites/npi/index.html. Accessed 5 July 2018

4. Alday PH, Doggett JS (2017) Drugs in development for toxoplasmosis: advances, challenges, and current status. Drug Des Devel Ther 11:273-293

5. Shigetomi K, Okada N, Kumaki T, Mitsuhashi S, Ubukata M (2018) Inhibitory activities of tree bark extracts against AGEs formation and their correlation with phenolic components. Wood Sci Technol 52:873-886

6. Dautu G, Ueno A, Miranda A, Mwanyumba S, Munyaka B, Carmen G, Kariya T, Omata Y, Saito A, Xuan X, Igarashi M (2008) Toxoplasma gondii: detection of MIC10 antigen in sera of experimentally infected mice. Exp Parasitol 118:362-371

7. Hehre W, Klunzinger P, Deppmeier B, Uchida N, Hashimoto M, Fukushi E, Takata Y (2017) Practical protocol for calculations ${ }^{13} \mathrm{C}$ chemical shifts for conformationally flexible natural products; scope and limitations. Abstract book of the 59th symposium on the chemistry of natural products. Sapporo, Japan, pp 169-172

8. Cole BJW, Bentley MD, Hua Y, Bu L (1991) Triterpenoid constituents in the outer bark of Betula alleghaniensis (yellow birch). J Wood Chem Technol 11:209-223

9. Minh TT, Anh NTH, Thang VD, Sung TV (2008) Study on chemical constituents of Salacia chinensis L. collected in Vietnam. Z Naturforsch B 63:1411-1414

10. Regasa CY, Galian RF, Arenal M, Tan V, Shen CC (2014) Triterpenes and sterols from Samanea saman. Res J Pharm Biol Chem Sci 5:1501-1507 
11. McLean S, Perpick-Dumont M, Reynolds WF, Jacobs H, Lachmansing SS (1987) Unambiguous structural and nuclear magnetic resonance spectral characterization of two triterpenoids of Maprounea guianensis by two-dimensional nuclear magnetic resonance spectroscopy. Can J Chem 65:2519-2525

12. Ogihara K, Iraha R, Higa M, Yogi S (1997) Studies on constituents from the twigs of Messerschmidia argentea (2). Bull Coll Sci Univ Ryukyus 64:53-59

13. Wang S, Fang W (2011) Design and synthesis of a dual linker for solid phase synthesis of oleanolic acid derivatives. Molecules 16:4748-4763
14. Tkachev AV, Denisov AY (1994) Oxidative decarboxylation by hydrogenperoxide and a mercury(II) salt - a simple route to nor-derivatives of acetyl oleanolic, acetyl ursolic and dehydroabietic acids. Tetrahedron 50:2591-2598

15. De Pablos LM, Gonzalez G, Rodrigues R, Granados AG, Parra A, Osuna A (2010) Action of a pentacyclic triterpenoid, maslinic acid, against Toxoplasma gondii. J Nat Prod 73:831-834

\section{Submit your manuscript to a SpringerOpen ${ }^{\circ}$ journal and benefit from:}

- Convenient online submission

- Rigorous peer review

- Open access: articles freely available online

- High visibility within the field

- Retaining the copyright to your article

Submit your next manuscript at $\boldsymbol{\nabla}$ springeropen.com 